\title{
Treatment of Subtrochanteric Fractures Using the Proximal Femoral Locked Plate
}

\author{
AMR W. FARAG, M.D.*; HERIF A. OSMAN, M.D.*; MOLHAM M. MOHAMMAD, M.D.*; \\ MOHAMED H. EL-AMIR ABORAS, M.Sc.**; BAHAALDINE S. ABD EL-WAHAB, M.Sc.*; \\ OMAR A.F. SHALABY, M.Sc.**; REDA A.A. SHETA, M.Sc.*; MOHAMED A. ABO KISHK, M.Sc.** and \\ MOMEN SEIF EL-NASR KHALAF, M.Sc.*
}

The Department of Orthopedic Surgery, Faculty of Medicine, Cairo University* and Damanhour Teaching Hospital**

\begin{abstract}
Background: Subtrochanteric femur fractures are one of the most devastating injuries. Most of the fractures in the elderly results from trivial fall while in the younger age group it is mainly due to high energy trauma. Fixing subtrochanteric fractures properly is clinically challenging. Various implants both intramedullary and extramedullary are available for their fixation.
\end{abstract}

Aim of Study: To evaluate the short-term outcomes of proximal femoral locking compression plate (PF-LCP) fixation for subtrochanteric femoral fractures.

Material and Methods: 30 patients with subtrochanteric fractures were operated upon with open reduction and internal fixation with proximal femoral locked plate. The Harris Hip score was used to document hip function at final follow-up.

Results: 28 patients were available for final follow-up after death of two patients. The mean age was 46.20 years The mean operative time was 125.6 minutes, mean incision length was $18.33 \mathrm{~cm}$, mean blood loss was $360 \mathrm{ml}$ and mean follow-up was 9.66 month. Union was achieved in all cases in 18.25 weeks. Complications included three cases of delayed union, five cases of superficial wound infection, two cases of malunion with varus deformity and shortening of 1.5 and $2 \mathrm{~cm}$. Final evaluation according to Harris Hip score was excellent in 15 cases $(53.6 \%)$, good in $11(39.3 \%)$ and fair in $2(7.1 \%)$.

Conclusion: The Proximal femoral LCP is a satisfactory and feasible method of treatment in subtrochanteric femur fractures.

Key Words: Subtrochanteric fractures - Proximal femurLocking compression plate.

\section{Introduction}

THE subtrochanteric zone of the femur is usually defined as the area extending from the lesser trochanter to a point $5 \mathrm{~cm}$ distally [1]. During the last 50 years, the treatment of subtrochanteric femoral

Correspondence to: Dr. Amr W. Farag, The Department of Orthopedic Surgery, Faculty of Medicine, Cairo University fractures has evolved with improved understanding of both fracture biology and biomechanics $[2,3]$. Early techniques of surgical repair demonstrated unacceptably high rates of complications; however, the benefits of restoring the anatomy and encouraging early mobilization are recognized and have led to significant research and improvement in implants [4]. The optimal method of management of these fractures remains a matter of debate. However, internal fixation is the treatment of choice for treating subtrochanteric fractures of the femur to obtain stability and best possible anatomic reduction [2,4]. The difficult nature of treating this fracture stems in part from the fact that this injury pattern is anatomically distinct from other proximal femoral peritrochanteric fractures and also from femoral shaft fractures. As a result, it must be treated with specially designed implants that can withstand significant muscular forces for prolonged periods of healing. These strong muscle forces deform the fracture fragments and make reduction difficult [5]. In addition, comminution is common in this region and implants must withstand significant early loading [6]. The locking compression plate with its fixed angle stable construct and high pull-out strength provides a stable fixation with less risk of cut out and loss of reduction [7]. The proximal femoral locked compression plate (PFLCP) is recommended for use in subtrochanteric fracture fixation. It minimizes soft tissue compromise and vascular insult to the injured bone in an attempt to optimize clinical results $[\mathbf{8 , 9}$. Here, we report the clinical trial of subtrochanteric fracture treatment with a Proximal Femur Locking Compression Plate (PFLCP). The objective of this study was to evaluate the outcome of subtrochanteric fractures treated with PF-LCP. 


\section{Patients and Methods}

During the period from May 2012 to December 2014,30 patients with subtrochanteric fracture femur aged 18-87 years were treated with proximal femoral locked plate and were undertaken at Kasr Al-Ainy. Faculty of Medicine, Cairo University. and Damanhour Teaching Hospital. Out of these one patient died on the 3 rd day of operation and another case died after 6 weeks leaving only 28 patients for final evaluation. Open and pathological fractures were excluded from this study. Detailed clinical conditions of all patients were recorded. Data recorded included age, sex, type of the fracture, side affected, mechanism of injury, associated injury, walking ability before fracture and preoperative delay. Operative data collected were operative time, intraoperative blood loss, incision length, $\mathrm{C}$ arm time, any intraoperative complications ordifficulty. Prophylactic intravenous 3 rd generation cephalosporin (cefotaxime) was taken preinduction to anaesthesia.

\section{Plate description:}

In this study we used stainless steel $4.5-\mathrm{mm}$ limited-contact proximal femoral locked plate anatomically precontoured to approximate the lateral aspect of the proximal femur. This plate is similar in design to a Synthes plate with the difference being in the size of the proximal cancellous locking screws and the screws are not cannulated. The three proximal locking holes of the plate are made for $6.5 \mathrm{~mm}$ locking head screws that are inserted at angles of $95^{\circ}, 120^{\circ}$ and $135^{\circ}$ respectively in relation to the shaft of the femur. The 3 rd screw intersects the path of the ${ }^{1 \text { st }}$ screw and act as a kickstand screw. Biomechanically, the kickstand screw increases the axial stiffness of the PF-LCP [10]. Fig. (1) the three proximal locking head screws have a purchase in the head of the femur in different planes increasing the stability of the construct. The distal part of the plate has combi holes for placement of either conventional or locking screws. This plate allowed anatomic reduction by its anatomic plate profile which assisted reduction of metaphysis to diaphysis and facilitated restoration of the neck-shaft angle by proper screw placement. The combination of conventional and locking screws offered optimum fixation irrespective of bone density. Limited-contact design reduces plate to bone contact and helps to preserve the periosteal blood supply.

\section{Surgical technique:}

Patient positioning: 23 patients were operated upon in lateral decubitus position on normal table and 7 patients operated upon in the supine position on fracture table. The bony prominences of the bottom limb were padded to avoid pressure necrosis of the skin. Incision: We made a longitudinal straight incision, beginning from the tip the greater trochanter and extended down the lateral side of the thigh over the lateral aspect of the femur. The length of the incision varied according to the case. The iliotibial band was incised longitudinally. We incised the fascia lata of the thigh in line with the skin incision. At the upper end of the wound, the distal portion of the tensor fasciae lata was splitted in line with its fibers to expose the vastus lateralis. The proximal vastus origin was released off of the vastus ridge of the greater trochanter (L-shape), then the muscle was retracted anteriorly to expose the lateral aspect of the femur [11].

\section{Fracture reduction and plate fixation:}

After exposure of the fracture site. We needed to obtain gross skeletal alignment using applied longitudinal traction and we needed preliminary fixation of the fracture fragments using $2.0 \mathrm{~mm} \mathrm{~K}$ wires or reduction forceps. Reduction aids were placed so as not to interfere with final plate placement. Interfragmenary screws needed to hold bone fragments and maintain fracture alignment. The screws were placed with counter sink or in directions away from site of application of the plate. Check position by $\mathrm{C}$ arm, then we thread the wire guides (sleeves) into the plate holes for each of the three proximal locking screws. For preliminary plate positioning, we used the guide wire technique under fluoroscopic image control in anteroposterior and lateral view. Then we drilled the bone with the drill bit. Placement of the proximal guide wire in the AP view was into the midportion of the inferomedial quadrant of the femoral head along a path subtending $50^{\circ}$ angle relative to the calcarfemoralis. Guide wire placement in this manner facilitated placement of the proximal locking screw at a $95^{\circ}$ angle to the femoral shaft [12] Fig. (2).

The plate was then fixed to the proximal fragment. Perfect placement of the plate to the proximal fragment was ensured, so that the tip of the plate was level with the tip of the greater trochanter. Then the plate was fixed distally with at least four locking screws [12]. At the end of the procedure, a drain was put and closure was done in layers. The drain was removed after 48 hours. Stitches were removed at 2 weeks. Partial weight bearing was allowed at 6 to 8 weeks and increased gradually according to callus formation and bone union. Patients were followed at 2, 6 weeks 3 months, 6 months and then till last follow-up and evaluated by Harris Hip score Figs. $(3,4)$. 


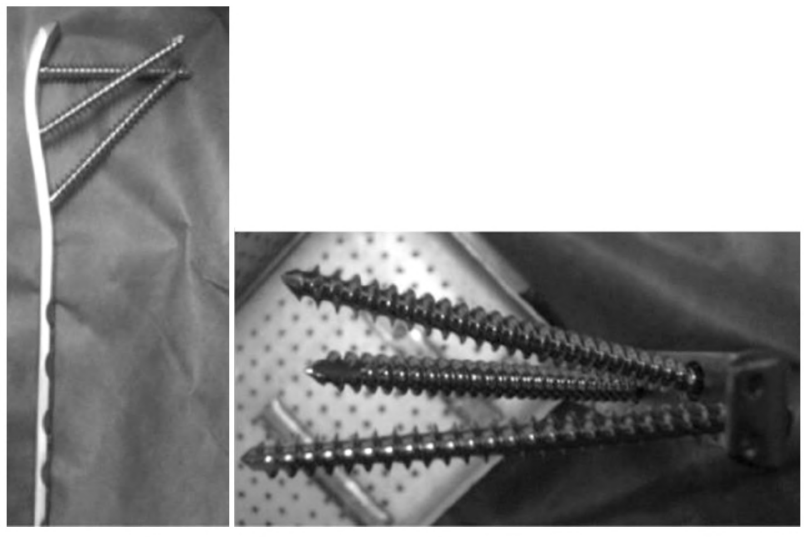

Fig. (1): PF-LCP.

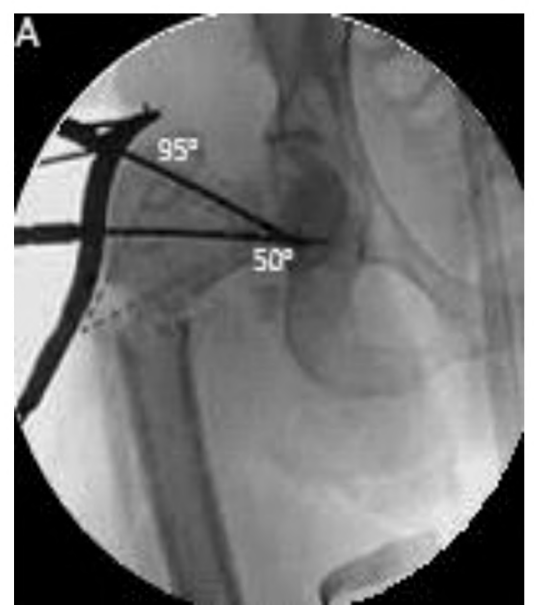

Fig. (2): Proper placement of the proximal screw [12].

\section{Results}

In this study the proximal femoral locked plate was used for the treatment of 30 patients with subtrochanteric femur fractures, 21 were males and 9 were females with mean age being 46.20 years, range from 18-87. Right side was affected in 17 cases and left side was affected in 13 cases. Two patient died, one on the $3 \mathrm{rd}$ post-operative day in ICU mainly due to pulmonary and chest problems, and the other died after 6 weeks. Leaving only 28 patients for final evaluation. The mechanism of injury included road traffic accident in 12 cases and fall to the ground (slipping) in 11 cases and 7 cases due to fall from height. As per Seinsheimer classification, the most common type in our study was type IV. There were 8 type IIB, 3 type IIC, 3 type III A 3 type III B, 9 type IV and 4 type V. In our series 9 patients presented with associated injuries and 21 patients present with isolated subtrochanteric fractures. The associated injuries were. 1 patient with ipsilateral fracture distal tibia. 3 patients with post-concussion. 1 patient with chest trauma, fracture ribs and ipsilateral hip subluxation with fracture head femur pipkin type 1, the patient was admitted to ICU. 2 patients with contralateral fracture distal end radius. 1 patient with ipsilateral lateral malleolus and contralateral calcaneous fracture. 1 patient with contralateral fracture shaft femur.

Mean operative time was $125.67 \mathrm{~min}$, range from (100min-160 minutes) the mean operative blood loss was $360 \mathrm{ml}$ with range from $250 \mathrm{ml}$ to $500 \mathrm{ml}$. With 11 patients received blood transfusion. Mean C-arm time was 2.067 minutes. Mean postoperative hospital stay was 4.77 days. Intra operative problems encountered were associated with fracture reduction along with difficulties relating to proper placement of the screws in the head of the femur in both anteroposterior and lateral planes on $\mathrm{C}$ arm images.

Among the 28 patients, 7 cases healed with no loss of position at the 3 months follow-up checkup and one case healed in 3 months but with breakage of the 1 st proximal screw and with no loss of position. 17 cases healed in an interval from 3 to 6 months with 3 cases only of delayed union $(10.7 \%)$. In one case the cause was deep infection and in 2 nd case, it was due to inadequate screws positions in the head and massive comminuted fragments. The third case was diabetic and hepatic with fracture comminution. In all three cases the fracture united without any other interference or bone grafting. The mean incision length was 18.33 $\mathrm{cm}$ and mean follow-up was 41,4 weeks. Average time to union was 18.25 weeks with range from 12-30 weeks.

Post-operatively, there were four cases of superficial wound infection and one case of deep wound infection. Superficial wound infection occurred in the second post-operative week in 4/29 patients. The infection was controlled within 7 days by using daily wound dressing and antibiotics as per culture and sensitivity. The case with deep infection needed debridement and controlled by tienam intravenous infusion. There was a significant relation between superficial infection and operation time. $p$-value 0.010 . Two patients had limb length discrepancy of 1.5 and $2 \mathrm{~cm}$ with varus angulation. $(7.1 \%)$. There were no reoperations except one debridement for infection.

All patients regained their walking and squatting ability by 6 month except 3 cases with delayed union. Five patients (15.9\%) complained of trochanteric pain and two of them developed trochanteric bursitis. Type IV and type V show higher statistically significant difference from type type IIB, type IIC, type III A and type III B in operative time. Post-operatively all patients were clinically 
assessed according to the Harris hip score. Excellent cases were $15(53.6 \%)$, good results were 11
$(39.3 \%)$ and fair were $2(7.1 \%)$. The mortality rate was 2 cases with percent of $6.6 \%$.
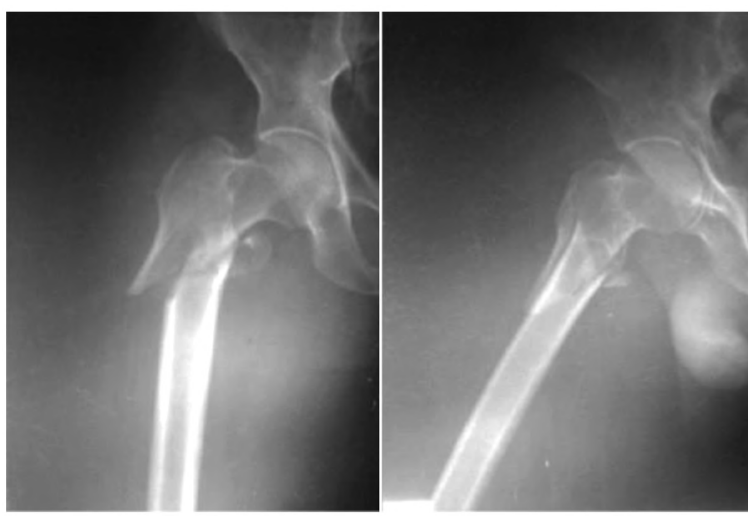

Fig. (3-A): Comminu
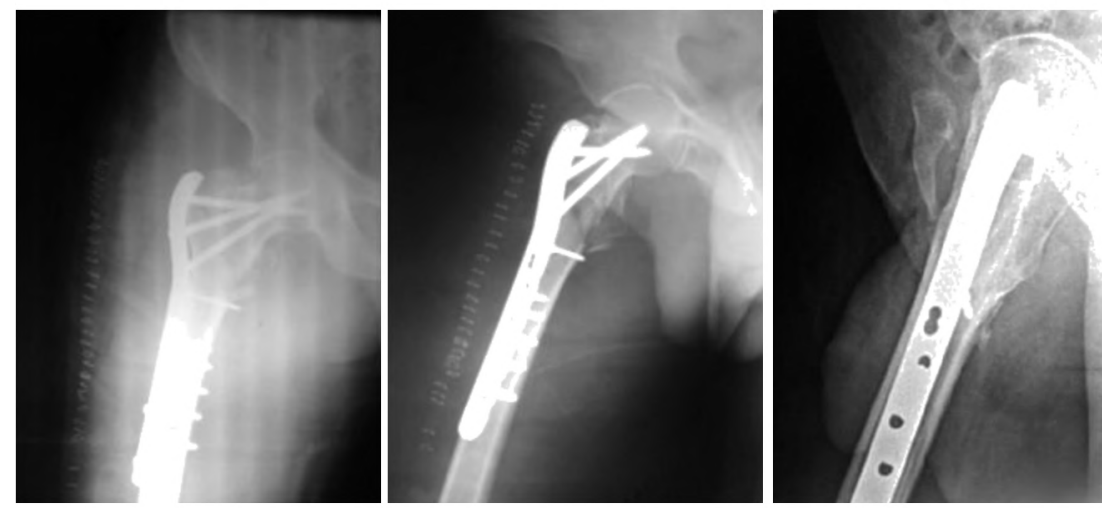

Fig. (3): Immediate post-operative radiograph
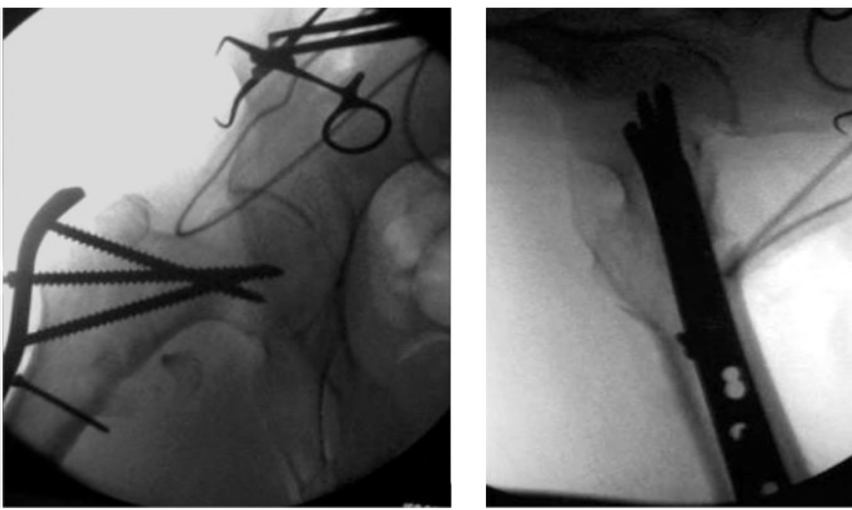

Fig. (3-B): Intra operative image.

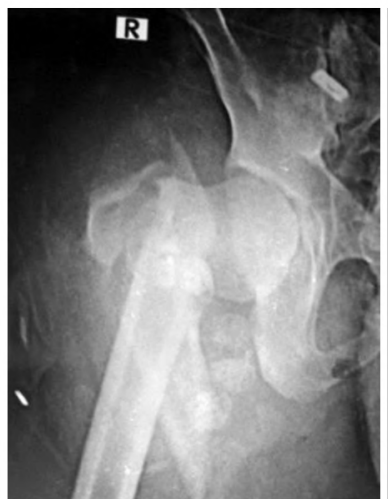

Fig. (4): Pre-operative X-ray.

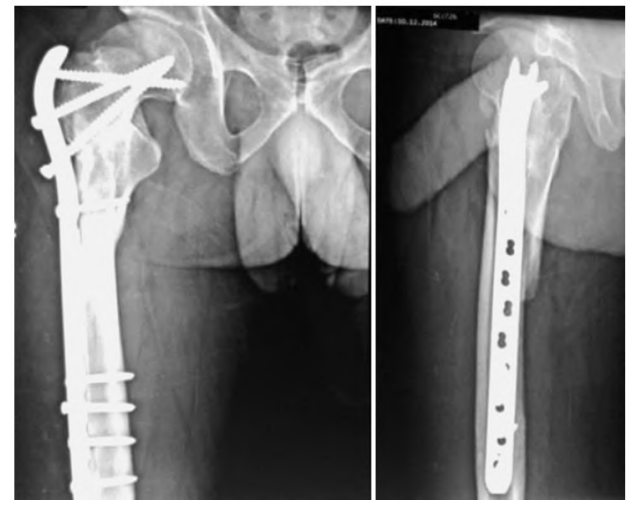

Fig. (4): X-ray after one year.

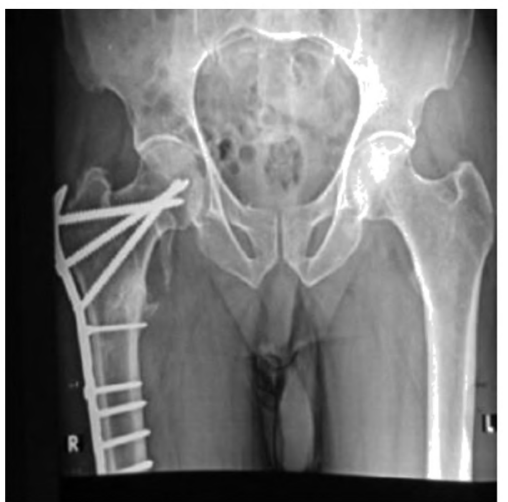

Fig. (3): X-ray after one year.

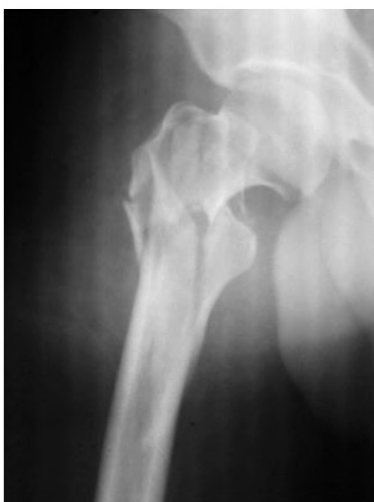

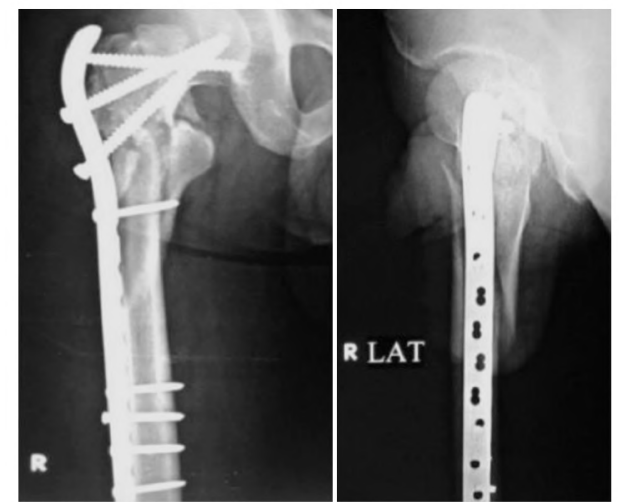

Fig. (4): Immediate post-operative X-ray.

\section{Discussion}

Fixation of subtrochanteric fracture, even for experienced surgeons, is a challenge [4].Various implants for the treatment of subtrochanteric fractures are available to address this type of fractures and their complications. The surgeons choose between the two methods according to Seinsheimer classification and also to their personal preference, extramededullary fixation and intramedullary nailing [13]. Extramedullary implants such as dynamic hip screw, dynamic condylar screw and angled 
blade plate when used in subtrochanteric fractures are associated with secondary varus collapse, cutout, implant failure and limb shortening on weight bearing due to medialization of the distal fragment. We found that proximal femur locking compression plate could reduce the rate of complications associated with use of these implants for subtrochanteric fractures.

Hasenboehler et al., [14] in 2007 first reported the use of the PFL-CP for comminuted subtrochanteric fractures and concluded that it is a feasible alternative for the treatment of unstable inter- and subtrochanteric fractures [14].

A biomechanical study by Britt D. Crist et al., [10] compared the LCP proximal femoral plate 4.5/5.0 with and without a kickstand screw, with a $95^{\circ}$ blade plate and a modified broad $4.5-\mathrm{mm}$ combination locking plate, in a composite femur subtrochanteric $30^{\circ}$ osteotomy fracture gap model. The PF-LCP with the kickstand screw provided higher axial but less torsional stiffness than the blade plate. This led to the conclusion that the PFLCP is essentially equivalent to the angled blade plate. The PF-LCP used in our series was similar to that used by Sasnur et al., [15]. Gunadham et al [16], Lee et al., [17] and Saini et al., [18] which is similar in design to the plate of Synthes with three proximal screws.

In our series, the operative blood loss was (360 \pm $96 \mathrm{ml})$ which was less than Lee et al., [17] (460) $\mathrm{ml}$ Gunadham et al., [16] (619 \pm 276$) \mathrm{ml}$ and Zhong et al., [19] who recorded blood loss of $(751.8 \pm 25) \mathrm{ml}$, but it was more than Sasnur et al., (180) $\mathrm{ml}$ [15], Saini et al., (233) $\mathrm{ml}$ [18] $\mathrm{Hu}$ et al., (230) $\mathrm{ml}$ [9] Zha et al., [20] (175) $\mathrm{ml}$ and Nishikant et al., (200) $\mathrm{ml}$ [21]. In our series, the mean skin incision length was $18.5 \mathrm{~cm}$. Which is considered a disadvantage and longer than that reported by Nishikant et al., [21], (10cm.) and Zha et al., [20] $(10.5 \mathrm{~cm})$. We explain our need for longer skin incision by the surgical approach with complete exposure of the fracture site and the need for anatomical or near anatomical reduction. This also was reported by $\mathrm{Hu}$ et al., [9] who concluded that precise reduction and strong fixation are the main objectives of the operation and closed reduction may not be able to achieve this goal but open reduction can.

In study by Pramod Saini et al., [18] they treated 32 cases of subtrochanteric fractures biologically with PF-LCP, operative time was 79.5 minutes, average blood loss was $233.13 \mathrm{ml}$ mean age was 44.7 years with no cases of implant failure or cut out. He concluded that PF-LCP is a suitable implant for comminuted subtrochanteric fractures for achieving high rates of union with minimal complications.

G.C. Zha et al., [20] found amongst the 110 patients with pertrochanteric fractures 12 cases with subtrochanteric fractures treated biologically with proximal femoral plate, the mean operation time was $40.70 \mathrm{~min}$. Their implant differ from the one used in this study in having four proximal threaded round holes distributed in a diamond shape in the plate made for cannulated $6.3 \mathrm{~mm}$ locking head screws inserted at an angle of $130^{\circ}$ in relation to the shaft of the femur. This study matches with the study of $\mathrm{Oh} \mathrm{CW}$ et al., [8] where twenty patients with subtrochanteric fractures (mean age 49.6 years) were prospectively treated using the MIPO technique using a locking plate but they used LCP of the distal femur of the contra lateral limb. In another study by Lee et al., [17] to review short-term outcomes of Proximal Femoral Locking Compression Plate (PF-LCP) fixation for proximal femoral fractures in terms of postoperative complications and failure rates, they concluded that the PF-LCP is appropriate for complex proximal femoral fractures with poor bone quality and multi-fragmentary subtrochanteric and proximal diaphyseal fractures.

\section{Conclusion:}

At present we consider that PF-LCP is a satisfactory method of fixation of subtrochanteric femur fractures but the operation is technically demanding. It is a good method of fixation but it is not the ideal implant especially in comminuted unstable fractures. The technique of plate application is not easy and takes long operative time with the risk of wound infection to place the proximal locking screw in the ideal position.

\section{References}

1- GRUBER J.E.: Injuries of the proximal femur. In: Rosen P., Barkin R., Danzl D.F., et al.: Editors. Emergency medicine: Concepts and clinical practice. $4^{\text {th }} \mathrm{ed}$. St. Louis: Mosby, 763-74, 1998.

2- CHAPMAN M.W.: Fracture of the hip and proximal femur. In: Chapman M.W. Lane J.M., Szoabo R.M., et al.: (eds) 3 rd edition Chapman's Orthopaedic Surgery, Lippincott Williams \& Wilkins, 19: 618-66, 2001.

3- BUCHOLZ R.W., HECKMAN J.D., COURT-BROWN C.M., TORNETTA P. and KOVAL K.J.: Rockwood and Green's Fractures in Adults: Rockwood, Green, and Wilkins' Fractures, 2 Volume Set. Sixth Edition. Lippincott Williams \& Wilkins, 2006.

4- LUNDY D.W.: Subtrochanteric femoral fractures. J. Am Acad. Orthop. Surg. Nov., 15 (11): 663-71. Review, 2007. 
5- EKSTRÖM W., NÉMETH G., SAMNEGÅRD E., DALEN N. and TIDERMARK J.: Quality of life after a subtrochanteric fracture: A prospective cohort study on 87 elderly patients. Injury. Apr., 40 (4): 371-6, 2009.

6- BOYD A.D. and WILBER J.H.: Patterns and complications of femur fractures below the hip in patients over 65 years of age. J. Orthop. Trauma., 6 (2): 167-74, 1992.

7- HAIDUKEWYCH G.J.: Innovations in locking plate technology. J. Am. Acad. Orthop. Surg., 12: 205-12, 2004.

8- OH C.W., KIM J.J., BYUN Y.S., OH J.K., KIM J.W., KIM S.Y., PARK B.C. and LEE H.J.: Minimally invasive plate osteosynthesis of subtrochanteric femur fractures with a locking plate: A prospective series of 20 fractures. Arch. Orthop. Trauma. Surg. Dec., 129 (12): 1659-65. doi: 10.1007/s00402-009-0815-y. Epub 2009 Jan 24, 2009.

9- SUN-JUN H.U., SHI-MIN ZHANG and GUANG-RONG Y.U.: The treatment of femoral subtrochanteric fractures with the proximal lateral femur locking plates. Acta. Ortop. Bras. [Online], 20 (6): 329-33, 2012.

10- BRITT D. CRIST, AFSHIN KHALAFI, SCOTT J. HAZELWOOD, MARK A. LEE., et al.: A biomechanical comparison of locked with percutaneous insertion capability versus the angled blade plate in a plate subtrochanteric fracture gap model. J. Orthop. Trauma. vol., 23 (9) 622-7, 2009.

11- HOPPENFELD, STANLEY, ROBERT HURLEY, De BOER and PIET: Surgical Exposures in Orthopaedics: The Anatomic Approach, 4 th Edition, 2009.

12- $4.5 \mathrm{~mm}$ LCP proximal femoral plate. Available from www. Synthes.com

13-CRAIG N.J., SIVAJI C. and MAVULLI N.: Subtrochanteric fractures. Review of treatment options. Bulletin Hospital for Joint Diseases, 60-35-46. (review article), 2001.

14- HASENBOEHLER E.A., AGUDELO J.F., MORGAN S.J., SMITH W.R., HAK D.J. and STAHEL P.F.: Treatment of complex proximal femoral fractures with the proximal femur locking compression plate. Orthopedics. Aug., 30 (8): 618-23, 2007.

15- SASNUR P.A., ISMAIL H., A.H. SASNUR and KIRAN B.: Surgical outcome of proximal femoral fractures using proximal femoral locking compression plate. Al Ameen J. Med. Sci., 8 (3): 235-8. US National Library of Medicine Enlisted Journal. ISSN 0974-1143, 2015.

16- GUNADHAM U., JAMPA J., SUNTORNSUP S. and LEEWIRIYAPHUN B.: The Outcome in Early Cases of treatment of subtrochanteric fractures with Proximal Femur Locking Compression Plate. Malays. Orthop. J. Jul., 8 (2): 22-8, 2014.

17- WEI TING LEE, DIARMUID MURPHY, FAREED H.Y. KAGDA and JOSEPH THAMBIAH: Proximal femoral locking compression plate for proximal femoral fractures. Journal of Orthopaedic Surgery, 22 (3): 287-93, 2014.

18- SAINI P., KUMARR., SHEKHAWAT V., JOSHI N., BANISI M. and KUMAR S.: Biological fixation of comminuted subtrochanteric fractures with proximal femur locking compression plate. Injury. Feb., 44 (2): 226-31, 2013.

19- BIAO ZHONG, Y. ZHANG, C. ZHANG and C-F. LUO: A comparison of proximal femoral locking compression plates with dynamic hip screws in extracapsular femoral fractures Orthopaedics \& Traumatology Surgery \& Research, 10/100 (6), 2014.

20- GUO-CHUN ZHA, ZE-LIN CHEN B., XIAO-BO QI B. and JUN-YING SUN A.: Treatment of pertrochanteric fractures with a proximal femur locking compression plates. Injury. Int. J. Care, Injured, 42: 1294-9, 2011.

21- NISHIKANT K., HIMANSHU KATARIA, CHANDRASHEKHAR YADAV, BHARATH S. GADAGOLI and RISHI RAJ: Evaluation of proximal femoral locking plate in unstable extracapsular proximal femoral fractures: Surgical technique \& midterm follow up results. J. Clin. Orthop. Trauma. Sep., 5 (3): 137-45, 2014. 


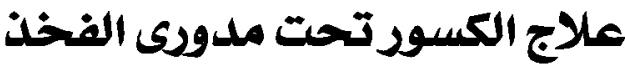 بواسطة الشريحة ذاتية الغلق ملتور الفي}

تعتبر الكسور تحت مدوى الفخذ من الكسور الشائعة وتوجد هذه الكسور فى مجموعتين من الأعمار. المجموعة الأقلى وهى مجموعة

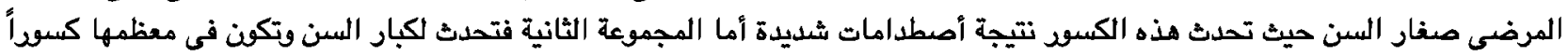

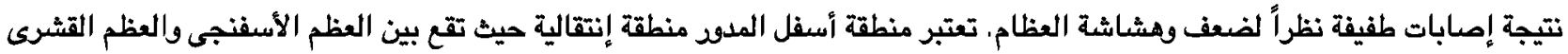

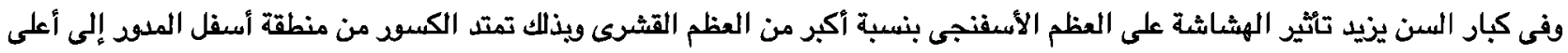

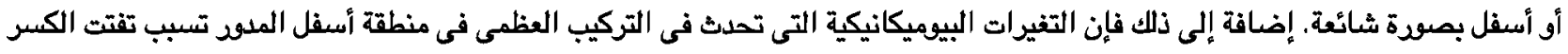

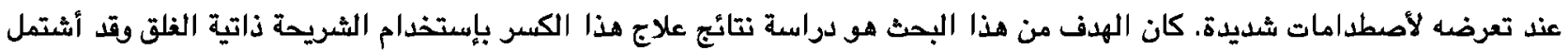
هذا البحث على جزئين:

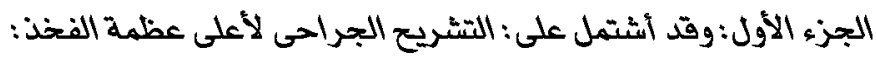
• إستعراض للآراء لمختلفة للباحثين في ميكانيكية حلوث هذه الكسود وصعوبة علاجها لأنها كسور غير مستقرة وتزداد هذه المشكلة البيوميكانيكية

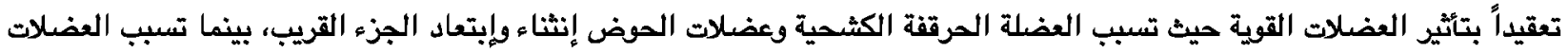
الضامة إزاحة داخلية الجزء البعيد.

• إستعراض لميكانيكية الشرائح الذاتية الغلق وإستخدامها ـ والطرق المختلفة لعلاج هذا الكسر.

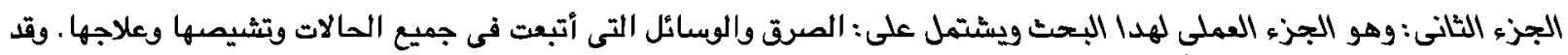

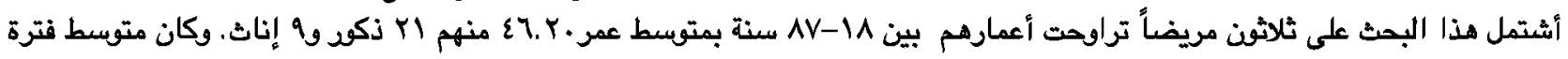

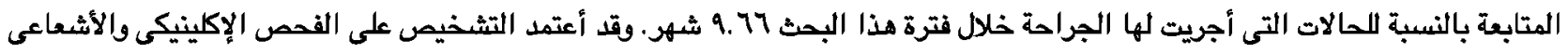

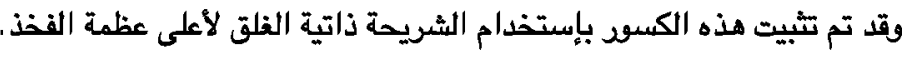

نتائج العلاج: تم تقييم النتائج بالنسبة لإستعادة المريض لحركته وألتحام الكسر طبقاً لطريقة هارس Haeeis Hip Score وقد كانت النتائج

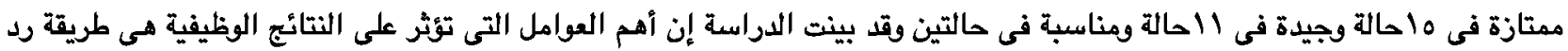

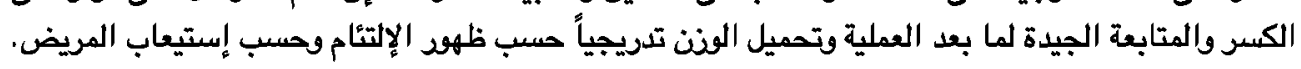

وقد أثبت إستعمال الشّريحة ذاتية الغلق فى العلاج الجراحى لكسوف أعلى عظمة الفخذ أنه وبسيلة جيدة للعلاج ويقلل من المضاعفات التى المئ تصدث فى الطرق الأخرى المعرفة. 